\title{
Klima výuky matematiky v angličtině (metodou CLIL)
}

\author{
Helena Binterová \\ Jihočeská univerzita, Pedagogická fakulta, Katedra matematiky
}

Redakci zasláno 8. 8. 2011 / Do tisku přijato 12. 3. 2012

\begin{abstract}
Abstrakt: Článek prezentuje výsledky případové studie zkoumající klima výuky matematiky na konkrétní základní škole. Studie prezentuje výsledky z výzkumných šetření prováděných v souvislosti se zavedením výuky matematiky v anglickém jazyce na této škole. Pro vyhodnocení klimatu výuky jsou použity jak kvantitativní metody sběru dat - dotazník, tak i metody kvalitativní - rozhovory s učiteli a žáky. Na základě vyhodnocení dotazníkového šetření ukazujeme rozdílnost klimatu výuky matematiky v jiném, než mateřském jazyce, z hlediska žáka i učitele. Zároveň naznačujeme možné prríčiny těchto rozdílů.
\end{abstract}

Klíčová slova: klima výuky, metoda CLIL, výukové prostředí

\section{1 Úvod}

Třída je sociální prostředí, $\mathrm{v}$ němž žáci tráví mnoho hodin během let vzdělávání, s životem ve třídě je spojeno mnoho zážitků. Proto je kvalita života ve třídě významná při utváření pocitů žáků, jejich postojů ke spolužákủm, učitelům, $\mathrm{k}$ výukovým předmětům a $\mathrm{v}$ neposlední řadě ke vzdělávání jako celku. Doba strávená v prostředí školy je cestou učení a nabývání sociálních zkušeností, které slouží jako základ pro rozvoj osobnosti, postojů k celoživotnímu vzdělávání a uplatnění se ve společnosti (Lambert \& McCombs, 1998; Lambert, Abbott-Shim, \& McCarty, 2002). Podmínkou nutnou, nikoli však postačující, je vytvoření správného sociálního klimatu; to je formováno vztahy mezi učiteli a žáky a vzájemnými vztahy mezi žáky, záleží na kvalitě těchto vztahů, na motivaci a výkonnosti žáků (Fraser, 1986). Pojem sociálního odkazuje na vlastnosti psychosociálního prostředí ve vzdělávacích zařízeních. Empirické studie a mezinárodní srovnávání ukazují, že existují výrazné rozdíly mezi školami v jejich sociálním klimatu. Dlouhodobé výzkumy prokazují, že školní klima má výrazný vliv na výsledky žáků ve škole, a dokonce i na úspěšnost jejich uplatnění po absolvování školy (Rutter, 2000). Fraser a Tobin (1991) konstatují, že klima třídy může být ovlivněno chováním studentů, úrovní znalostí, jejich studijními výsledky, 
motivací, postojem k vyučované oblasti a vzdělání jako celku. Pokud je klima třídy nepřátelské, objevují se pocity úzkosti, neklidu a skepse, které mohou vést $\mathrm{k}$ intelektuální a poznávací depresi. Na druhé straně, ve tř́dách, jejichž klima je příznivé, s rozpoznatelnou sebeúctou žáků i navzájem, dochází ke zlepšení schopností žáků.

Tento text si klade za cíl představit výsledky výzkumu, který se zabývá tématem klima výuky matematiky. Výzkumné šetření proběhlo formou př́padové studie v souvislosti se zavedením výuky matematiky v anglickém jazyce na konkrétní škole. Na základě vyhodnocení dotazníkového šetření ukazujeme rozdílnost klimatu výuky matematiky $\mathrm{v}$ jiném, než mateřském jazyce, z hlediska žáka i učitele a zároveň naznačujeme možné příčiny těchto rozdílů.

\section{Konceptuální vymezení}

\subsection{Vymezení pojmu klima výuky}

Existují a jsou popsána různá pojetí klimatu školy, tř́ídy, výuky. Úkolem tohoto článku není úplné zavedení všech souvisejících pojmů. Pokusme se vymezit pojem klimatu výuky tak, jak ho budeme pro potřeby našeho zkoumání chápat a interpretovat. Mareš (2000, s. 242) chápe klima školy jako „ustálené postupy vnímání, prožívání, hodnocení a reagování všech aktérů školy na to, co se ve škole odehrálo, právě odehrává nebo má v budoucnu odehrát", toho využijeme k vymezení pojmu klima výuky. Toto klima charakterizujeme jako sociální jev. Obsahově zahrnuje vnímání, prožívání žáků a jejich hodnocení situací, ke kterým ve třídě při výuce dochází. Klima výuky matematiky chápeme jako určitou kvalitu školního prostředí, životního prostoru žáků, která se tvoří při vyučování matematice. Žáci ji určitým způsobem vnímají a je možné ji charakterizovat. Klima výuky matematiky je reakcí žáků na prostředí, ve kterém výuka probíhá. Povaha klimatu výuky je relativně stabilní a není homogenní.

Model sociálního klimatu výukového prostředí byl popsán např́klad z hlediska konceptualizace univerzálních lidských hodnot (Schwartz, 1992, s. 14), Allodi (2007) jej popsal z hlediska všeobecných lidských hodnot a kvality výukového prostředí z pohledu žáků. Jejich modely můžeme použít $\mathrm{k}$ popisu a hodnocení výukových prostředí. Nedílnou součástí posouzení kvality výukového prostředí je hodnocení kreativity, stimulace, výkonu, 
účinnosti, bezpečnosti, ovládání, vstřrícnosti, otevřenosti ke změně aj. (Allodi, 2007, s. 165). Neexistuje však zatím studie, která by vedla k jednoznačnému vymezení problému, zda (a do jaké míry) jsou rozdíly v klimatu výukového prostředí zapř́ćciněny obsahem výuky, nebo znaky souvisejícími s kvalitami učitelů a žáků, popř. dalšími ukazateli (Grecmanová, 2008, s. 63). Otázka souvislosti mezi vyučovacím předmětem, kurikulem a klimatem školy je stále výzkumně otevřená. $\mathrm{V}$ matematickém vyučování bude jistě rozdílné klima výuky geometrie a algebry. Ani otázka, zda je klima školy závislé na vyučovacím předmětu, není dosud zodpovězena (Grecmanová, 2008, s. 61). Výsledky např́iklad ukazují na fakt, že klima výuky matematiky je podporující - má jasně vymezená pravidla a je charakteristické relativně vyšším významem vztahů mezi žáky.

\subsection{Metoda CLIL}

Lave (1988) a Salomon (1992) tvrdí, že při měření a testování klimatu výuky bychom měli vzít v úvahu též existující metody vyučování. Metodou vyučování, která je v centru zkoumání naší studie, je metoda CLIL. V České republice došlo v posledních letech na základních školách a nižším stupni víceletých gymnázií $\mathrm{v}$ souvislosti $\mathrm{s}$ přechodem $\mathrm{k}$ rámcovým vzdělávacím programům ke změnám vzdělávacího obsahu a učebních osnov. Školní vzdělávací programy nabízejí školám možnost měnit výuku stávajících vzdělávacích předmětů, volit ve vzdělávacím procesu netradiční učební metody nebo se určitým způsobem profilovat. $V$ rámci školních vzdělávacích programů je možné zvolit také výuku metodou CLIL (z anglického Content and Language Intergrated Learning - výuka nejazykových předmětů, např. matematika, dějepis, biologie, v jiném než mateřském jazyce; viz Marsh, 2000; Oxford, 2001; Lange, 2002; Davies, 2003).

Využití druhého jazyka ve vyučování se objevilo již v době antiky, a to jak v Řecku, tak v Římě (Lewis, 1977, s. 31). Existovaly však i alternativní formy dvojjazyčného vzdělávání. V současné době se na základních, středních a vysokých školách na celém světě rozvíjí výuka nejazykových předmětů v cizím jazyce.

Na základě zkušeností publikovaných o CLIL se ukazuje, že nejlepších výsledků dosahují učitelé, kteří mají požadované vzdělání jak v příslušném jazyce, tak i v odborném předmětu. Marsh (2000, s. 43) tvrdí, že užití jiného než mateřského jazyka ve vyučování také vyžaduje přizpůsobení výukových 
metod. To prokázali ve svých výzkumech například Snow, Met a Genesee (1989) a Swain a Lapkin (1982). Marsh se zmiňuje především o následujících faktorech ovlivňujících použité metody výuky či vlastnosti výukového prostředí: vizualizace a ilustrativnost, zjednodušení výuky - zjednodušení slovníku, zvýšení využití písemných materiálů, opakování - vysvětlení stejné věci několikrát, s opakováním, nebo parafrázováním, kontrola porozumění identifikace problémů, které žákům činí potíže jak z hlediska koncepce, tak jazyka.

Kvalitu výuky matematiky řeší výzkumy reagující na výsledky srovnávacích studií TIMSS a PISA (Stigler \& Hiebert, 1999; Learner's Perspective Study ${ }^{1}$ aj.). Jejich výsledky ukazují, že je obtížné označit výuku matematiky za optimální. $\mathrm{V}$ některých zemích je za takovou výuku považována frontální výuka, jinde je to výuka orientující se více na žáky. Dreesmann (1982) poukazuje na výsledky, $\mathrm{z}$ nichž vyplývá, že při výuce matematiky většinou chybí individuální př́ístup k žákům, chybí komunikace, je zde patrný tlak na žáka směrem k výkonu, výuka je formální (z pohledu žáků), žáci prožívají horší vzájemné vztahy. Důraz je kladen především na pamětné učení, komparaci, syntézu (Grecmanová, 2008, s. 62).

\section{Cíl příspěvku a metodika výzkumu}

Naše empirická studie je inspirována výsledky zmiňovaných výzkumů a pracuje s daty terénního šetření. Jejím cílem je ukázat, že ve spojení předmětů matematika a angličtina nemusí dojít $\mathrm{k}$ tomu, co konstatuje Dreesmann (1982, s. 129); podle něho je klima výuky matematiky a výuky angličtiny rozdílné. Metodou CLIL je možné docílit odstranění rozdílností např. v kompetencích komunikativních, $\mathrm{k}$ řešení problému, $\mathrm{k}$ učení.

Cílem naší studie je analyzovat, komparovat a popsat klima výuky matematiky v angličtině na základní škole, a následně určit jeho rozdílnost od klimatu výuky v češtině. Chceme dokázat, že při výuce matematiky metodou CLIL bude hodnocení klimatu výuky pozitivnější.

Použitou výzkumnou metodou této studie je dotazník pro žáky. Sledovali jsme

\footnotetext{
Learner's Perspective Study (http://www.lps.iccr.edu.au/ je mezinárodní projekt, který navazuje na výzkum TIMSS. Zkoumá výuku matematiky z pohledu žáka komplexněji, na základě rozboru videozáznamů z vyučovacích hodin. Výzkumné týmy pracují v šestnácti zemích, v Austrálii, Číně, České republice, Německu, Izraeli, Japonsku, Koreji, Novém Zélandu, Norsku, Filipínách, Portugalsku, Singapuru, Jižní Africe, Švédsku, Velké Británii a USA. Autorka studie je členkou výzkumného týmu v České republice.
} 
klima při výuce matematiky uskutečňované v cizím jazyce (angličtině), tedy metodou CLIL, v prủběhu projektu Propojení cizího jazyka a matematiky na základní škole 2 . Prováděli jsme dlouhodobá pozorování a zjistili jsme, že žáci byli $\mathrm{v}$ hodinách matematiky $\mathrm{v}$ angličtině prokazatelně více motivováni než v hodinách matematiky v českém jazyce, což se projevilo na jejich aktivitě ve vyučovacích hodinách. Při analýze videonahrávek a při hospitacích v hodinách jsme pozorovali změnu vyučovacích metod na metody aktivizující (oproti hodinám bez výuky matematiky v angličtině), růst aktivity, změnu prostředků komunikace. Při testování žáků při vyučování v angličtině jsme méně často diagnostikovali formalismus než při testování dětí v běžných třídách, žáci nebyli směřováni pouze k hledání správných řešení, ale i k jejich zdůvodňování, obhajobě, diskuzi.

Klima výuky, jak již bylo řečeno, může být ovlivněno mnoha proměnnými. Výzkumy klimatu výuky popisují postoj ke klimatu ze strany žáků, učitelů a rodičů. Grecmanová $(2008$, s. 117) uvádí, že velkou pomocí při interpretování údajů jsou v takovém př́ípadě výpovědi žáků, kteří většinou odpovídají pravdivě a své výpovědi nenadhodnocují. Proto jsme se rozhodli přistoupit k šetření v rovině žáků, jejich postojů a hodnocení. Klima ve výuce matematiky v anglickém jazyce jsme sledovali v letech 2010-2011 na třech základních školách ${ }^{3}$.

2 Základní škola Matice školské (www.zsmatice.cz) v Českých Budějovicích a Pedagogická fakulta Jihočeské univerzity v Českých Budějovicích v současné době pracují na společném projektu Propojení cizího jazyka a matematiky na základní škole financovaném ze Strukturálních fondů Evropské unie. Řešení tohoto projektu bylo zahájeno v únoru 2009, celková doba trvání projektu je 29 měsíců, počet tř́íd v projektu 14. Jeho cílem je zejména vytvoření a zveřejnění materiálů a výukových prostředí pro výuku vybraných předmětů $\mathrm{v}$ anglickém jazyce na základní škole $\mathrm{v}$ podobě mezipředmětových výukových modulů a jejich rozpracování do klíčových kompetencí s cílem jejich následného rozvoje. Konkrétně se jedná o modul Matematika v angličtině pro 4.-9. ročník a Výtvarná výchova v angličtině pro 4.-9. ročník.

3 Jedná se o výzkum pokrývající více dimenzí, především sledování posunu ve znalostech žáků v matematice, jejich vztahu k matematice, angličtině, škole, budoucímu povolání aj. Metody, které volíme, jsou kvantitativní (dotazníková šetření, testy) i kvalitativní (videonahrávky, pozorování). Data pro výzkum sbíráme na vzorku žáků uvedené základní školy od června roku 2009 a v měření budeme pokračovat do roku 2012. Do projektu se zapojila celá škola, tedy žáci 4.-9. tříd; škola je garantem projektu. Dále na projektu dobrovolně spolupracují dvě základní školy (jedna škola z Jihomoravského kraje, z malého města, druhá z malé obce v Jihočeském kraji) účastí jedné až dvou tříd. Školy nebyly nijak vybírány, projekt je vyústěním spolupráce základních škol s PF JU. Vyučujících, kteří se podíleli na výuce matematiky v angličtině, je celkem 9 . K metodám vyhodnocení těchto dat patří dvouvýběrový test, Wilcoxonův test a znaménkový test pro nezávislé soubory, Chí-kvadrát test. 


\subsection{Výuka matematiky v angličtině na základní škole - popis}

Vyučující (k dispozici jsme jich měli 9) v první fázi projektu v běžných hodinách matematiky často nepoužívali informační technologie ve výuce. Po půl roce začali vypracovávat pracovní listy a výukové materiály pro výuku matematiky s využitím moderních technologií (interaktivních tabulí, matematických programů). Materiály pro výuku jsou v současné době zpracovány $\mathrm{v}$ interaktivní podobě a jsou ozvučené (nová slovíčka a větná spojení namluvili spolupracující rodilí mluvčí). Všechny materiály jsou zpracované v souladu s RVP, jsou tedy rozpracované do klíčových kompetencí a jsou stanoveny očekávané výstupy jednotlivých hodin z hlediska žáka. Výuku matematiky museli vyučující koncipovat tak, aby co nejvíce zohlednila motivační fázi pojmotvorného procesu, aby v co nejvyšší možné míře využila interaktivní prvky vytvořených výukových prostředí a aby byly využity matematické programy s cílem vytvářet co nejvíce matematických situací v mnoha rozmanitých kontextech prostřednictvím cizího jazyka - a tím byla vytvářena matematická gramotnost žáků se zřetelem na jazykovou stránku předmětu.

Publikace Koncepce matematické gramotnosti ve výzkumu PISA 2003 (s. 5) vymezuje pojem matematická gramotnost jako schopnost jedince poznat a pochopit roli matematiky ve světě, jako schopnost vymezit, formulovat a řešit problémy z různých oblastí a kontextů a interpretovat jejich řešení s užitím matematiky. Definice se netýká pouze matematických znalostí na určité úrovni, ale jde v ní o používání matematiky v celé řadě situací, od jednoduchých až po složité4.

Výuka matematiky $\mathrm{v}$ angličtině probíhala nejméně jedenkrát týdně (maximálně však dvakrát), a to dle volby vyučujících v různých fázích zavedení pojmu, procvičení, testování znalostí apod. Vyučující se do projektu zapojili dobrovolně, věnovali př́ípravě výukového prostředí hodně času a také pracovali na jeho následném zkvalitňování. Běžné byly reflexe a diskuze, které se týkaly zjištoování nedostatků, projednávání strategií, jak postupovat dál a případně, co změnit, plánování postupu př́ípadné změny výukového prostředí. Všechny vyučující bychom mohli označit jako zkušené, s dobrým vztahem k dětem, nadšené dělat něco nového. Hodiny matematiky vyučované

4 Volně z publikace Koncepce matematické gramotnosti ve výzkumu PISA 2003 (2004), jako překlad The PISA 2003 assessment framework - mathematics, reading, science and problem solving knowledge and skills (2003). 
metodou CLIL byly promyšlené (i díky připraveným interaktivním výukovým prostředím), výuka byla proporcionální, vyučující vedli děti ke správnému používání jazyka matematiky i ke správné komunikaci v angličtině. Navíc byli žáci dostatečně flexibilní, integrovali nové technologie do výukového prostředí tak, že z restrukturalizace formy výuky mělo prospěch co největší množství žáků. Výuka $\mathrm{v}$ hodinách matematiky probíhala $\mathrm{v}$ duchu konstruktivismu a problémového vyučování.

Matematika byla žákům představována jako vědní disciplína s logickou výstavbou, a to se snahou odstranit obavy z matematiky, navíc s nácvikem logické argumentace a matematizace úloh. Žáci se seznamovali s problémovými úlohami s přesahem do běžného života. Pomůcky (aplety, animace, programy), které byly v hodinách používány, přispívaly k vytváření matematické gramotnosti v uvedeném významu, žáci i jejich prostřednictvím více spolupracovali, aktivně se zapojovali do výuky. Výuka geometrie byla obohacena o nový nástroj, rýsování v geometrickém náčrtníku GeoGebra (počítačový program, prostředí s možností změny jazyka), a tím se stala pro žáky atraktivnější. Kromě matematických dovedností získávali ještě dovednosti jazykové a technické. Organizace výuky byla většinou dobrá a žáci se proto cítili dobře a dokázali se koncentrovat celou vyučovací hodinu. Počáteční obavy $\mathrm{z}$ angličtiny, které jsme si dobře uvědomovali v průběhu hospitací u většiny žáků, zmizely. Důvodem mohlo být atraktivní prostředí, nové metody práce v matematice, hodnocení, využití interaktivní tabule aj. Úroveň matematických dovedností a základní matematické kompetence jsme průběžně testovali.

Grecmanová (2008, s. 70) uvádí, že žák s pozitivním uvědoměním si sama sebe považuje výuku za méně obtížnou a srozumitelnější. Výuka dostává nový smysl, žák ji vidí jako možnost být oceněn a přeje si na jejím průběhu participovat.

\subsection{Organizace sběru dat}

Data pro toto šetření byla sebrána od žáků 6.-8. tříd (celkem 6) základní školy. Pro možnost porovnávání dat jsme vzorek žáků omezili na třídy, ve kterých vyučovala jen jedna $\mathrm{z}$ vyučujících zúčastněných $\mathrm{v}$ projektu. Respondentů, kteří prošli výukou matematiky v angličtině (dále M/A), bylo 78. Kontrolní skupinu tvořilo 97 respondentů. Tuto kontrolní skupinu žáků, kteří výuku matematiky v angličtině ve školním roce 2010/2011 neabsolvovali, dále 
budeme označovat jako skupinu M. Skupiny byly vyrovnané co do počtu dívek a chlapců. Helmke a Weinert (in Grecmanová, 2008, s. 69) ve svých výzkumech prokazují, že počet dívek ve tř́dě ovlivňuje hodnocení klimatu třídy ve většině předmětů (čím vyšší je podíl dívek, tím příznivější je klima), jen u matematiky jsou rozdíly. Dívky považují vyučování matematiky za méně srozumitelné a neprožívají tolik kamarádské vztahy či naději na úspěch.

\subsection{Popis dotazníku}

Pro náš experiment jsme nesestavovali vlastní dotazník, ale použili jsme dotazník pro výzkumné šetření o klimatu výuky př́rodovědných disciplín Dotazník $k$ posouzení stavu výuky $v$ jednotlivých vyučovaných predmětech (Grecmanová, 2008, s. 184), dále jen G. Na konci prvního roku výuky matematiky v angličtině byl všem žákům uvedených tříd tento dotazník zadán (tabulka 1), s cílem zjistit, zda bude hodnocení klimatu výuky jiné zavedením výuky CLIL - a pokud ano, tak v jakých kategoriích. Porovnání provedeme jednak vzhledem k výsledkům šetření $\mathrm{G}$, ale také vzhledem ke znaku Výuka metodou CLIL ano, ne.

Dotazník G je koncipován jako 26 tvrzení, ke kterým respondenti zaujímají vlastní postoj volbou odpovědi pětistupňové stupnice 1 - vždy, 2 - skoro vždy, 3 - někdy, 4 - skoro nikdy, 5 - nikdy. Pro snadnější vyhodnocení dotazníku jsou jednotlivá tvrzení spojena do sedmi kategorií K1-K7: K1 představuje učitelovo nadšení a rozhled, schopnost zaujmout (otázky 86, 89, 98, 99), K2 hodnotí netradiční způsob výuky, aktivitu a spolupráci (otázky 81, 85, 93, 94), K3 učitelovu podporu a zájem o žáka $(82,83,84,96)$, K4 je kategorií hodnotící spravedlivý přístup $(74,90,91)$, K5 řeší smysluplnost výuky (tvrzení 75, 87, 88, 92), kategorie K6 hodnotí přiměřenost požadavků (tvrzení 79, 80, 95) a K7 pak přehlednost $(76,77,78,97)$.

\section{$4 \quad$ Výsledky a interpretace}

Při vyhodnocování dotazníků byly použity metody popisné statistiky. $\mathrm{V}$ případě zajímavých vztahů bylo provedeno dvojné třídění získaných dat. Výsledky šetření uvádíme v tabulce 2 a v grafu na obrázku 1. Čím je hodnota v tabulce nižší, tím je příznivější vnímání dané kategorie. $Z$ výsledků je zřejmé, že žáci skupiny $M$ na uvedené základní škole se výrazně neliší v hodnocení klimatu výuky od hodnocení žáků ve výzkumu G klimatu přírodovědných disciplín. Žáci s M/A kladně hodnotí přehlednost výuky a schopnost učitele 
zaujmout a jeho nadšení (průměrná hodnota 1,84; 1,92). Kategorií s nízkým ohodnocením je také, jako v G, netradiční způsob výuky, aktivita a spolupráce (průměrná hodnota $M / A$ 2,77). $Z$ tabulky 2 však vidíme, že došlo $k$ výrazným rozdílům v odchylkách hodnocení žáků $\mathrm{M} / \mathrm{A}$ a $\mathrm{G}$. $\mathrm{V}$ této relaci se pozitivně změnilo hodnocení kategorie K5 - Smysluplnost výuky. Dále došlo k odchýlení hodnocení důležité kategorie K2 - Netradiční způsob výuky, aktivita a spolupráce. Tato kategorie je podle šetření $\mathrm{G}$ u žáků základních a středních škol hodnocena nejhůře.

\section{Tabulka 1}

Vybrané otázky z dotazníku G

\begin{tabular}{lll}
\hline Tvrzení & Číslo & $\begin{array}{c}\text { Hodnocení } \\
\text { 1 až 5 }\end{array}$ \\
\hline Svůj názor sděluji učiteli bez obav & 74 \\
Názor musím vysvětlit & 75 \\
Jsou jasně stanovená pravidla práce při výuce & 76 \\
Úkoly musím plnit přesně a spolehlivě & 77 \\
Úkoly jsou průběžně kontrolovány & 78 \\
Úkoly jsou přiměřené tomu, co jsem se naučil & 79 \\
Domácí přípravu na výuku zvládám bez problémů & 80 \\
Dobré nápady mohu ve výuce uplatnit & 81 \\
Učitel mě podporuje, když mě v rámci předmětu něco zajímá & 82 \\
Když nestačím plnit úkoly ve výuce, dostane se mi pomoci & 83 \\
Když splním úkoly rychleji než ostatní, učitel mě dále zaměstná & 84 \\
Výuka probíhá i mimo školu & 85 \\
Učitel vyučuje zajímavě a s nadšením & 86 \\
Učitel nám vysvětlí, jak a kde využít toho, co jsme se naučili & 87 \\
Učitel nám sdělí, ve které profesi je probírané učivo uplatněno & 88 \\
Učitel využívá názorné př́́klady a pomůcky & 89 \\
Výsledky mé práce ve výuce jsou spravedlivě hodnoceny & 90 \\
Před zkoušením jsem v pohodě & 91 \\
Při zkoušení je prověřováno, jak látce rozumím & 92 \\
Při plnění úkolů pracujeme ve skupinách & 93 \\
Jsme vedeni k tomu, abychom o postupech při plnění úkolů ve výuce & 94 \\
diskutovali se spolužáky & \\
Než přejdeme k novému učivu, učitel se nás zeptá, co o nové látce již & 95 \\
víme & \\
Učitel má radost, když se mi ve výuce daří & 96 \\
Učitel se ve výuce věnuje probíranému učivu, neodbíhá od tématu & 97 \\
Způsobem výuky udržuje učitel moji pozornost & 98 \\
Učitel odpovídá žákům na otázky týkající se učiva & 99 \\
\hline
\end{tabular}


Tabulka 2

Srovnávací tabulka klimatu výuky

\begin{tabular}{lccccccc}
\hline $\begin{array}{l}\text { KATEGORIE } \\
\text { (průměrná hodnota) }\end{array}$ & $\mathbf{G}$ & $\mathbf{M} / \mathbf{A}$ & $\mathbf{M}$ & $\begin{array}{c}\text { odchylka } \\
\text { M/A od G }\end{array}$ & $\begin{array}{c}\text { odchylka } \\
\text { M od G }\end{array}$ & $\begin{array}{c}\text { odchylka } \\
\text { M/Aj od M }\end{array}$ & $\begin{array}{c}\text { p-value } \\
\text { M/Aj a M }\end{array}$ \\
\hline $\begin{array}{l}\text { K1 } \\
\text { (nadšení) }\end{array}$ & 2,33 & 1,92 & 2,46 & 0,41 & $-0,13$ & 0,54 & 0,000002 \\
$\begin{array}{l}\text { K2 } \\
\text { (netradiční výuka) }\end{array}$ & 3,62 & 2,77 & 3,09 & 0,85 & 0,53 & 0,32 & 0,003735 \\
$\begin{array}{l}\text { K3 } \\
\text { (podpora žáka) }\end{array}$ & 2,52 & 2,08 & 2,52 & 0,44 & 0 & 0,44 & 0,000211 \\
$\begin{array}{l}\text { K4 } \\
\text { (spravedlivý přístup) }\end{array}$ & 2,64 & 2,06 & 2,65 & 0,58 & $-0,01$ & 0,59 & 0,000004 \\
$\begin{array}{l}\text { K5 } \\
\text { (smysluplnost výuky) }\end{array}$ & 2,8 & 2,2 & 2,57 & 0,6 & 0,23 & 0,37 & 0,000671 \\
$\begin{array}{l}\text { K6 } \\
\text { (přiměřenost) }\end{array}$ & 2,43 & 1,96 & 2,34 & 0,47 & 0,09 & 0,38 & 0,004794 \\
$\begin{array}{l}\text { K7 } \\
\text { (přehlednost) }\end{array}$ & 2,11 & 1,84 & 2,12 & 0,27 & $-0,01$ & 0,28 & 0,003732 \\
\hline
\end{tabular}

Naopak hodnocení skupiny M v kategorii K1 - Nadšení učitele a schopnost zaujmout je horší, tato změna je dána odchylkou $\mathrm{M}$ vzhledem $\mathrm{k}$ šetření $\mathrm{G}$. Zbylé třri ze sledovaných kategorií se ve shodě s G umístily ve středu škály hodnocení a nevykazují žádné výrazné rozdíly.

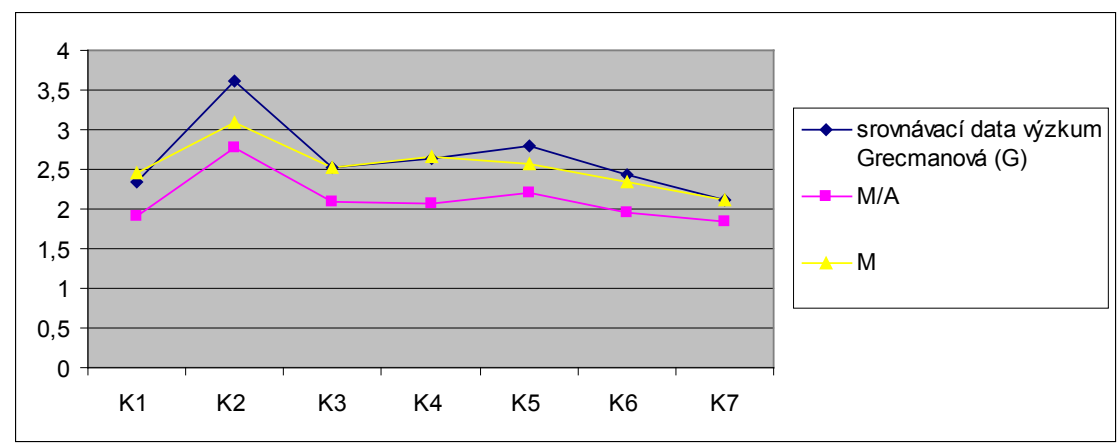

Obrázek 1. Hodnocení výuky matematiky na ZŠ. 
Zhodnocením sledované výuky matematiky u jedné vyučující ( $\mathrm{v}$ našem šetření) po kategoriích dojdeme k závěru, že ve všech kategoriích se hodnocení liší, a to $\mathrm{v}$ průměru o 0,42 bodu uvedené stupnice. Výuka této vyučující je v kategorii Netradiční způsob výuky, aktivita, spolupráce (K2) žáky $M$ hodnocena pozitivněji než výuka matematiky v G, ale žáci M/A ji hodnotí ještě vyšším ohodnocením (o 0,32 bodu), a to dokonce o 0,85 bodu lepším než v G (čím je hodnota odchylky vyšší, tím příznivější je hodnocení klimatu). To vyplývá z charakteristiky učitelky a dále z uvedených skutečností, že se metoda CLIL vyznačuje potřebou využití nových metod při výuce. $\mathrm{V}$ této kategorii $\mathrm{K} 2$ žáci hodnotili v podstatě kvalitu výukového prostředí, stejně jako v kategorii K6 a K7. Z výsledků šetření je vidět, že přiměřenost požadavků a přehlednost výukového prostředí hodnotí M žáci stejně jako v G, ale žáci M/A tyto aspekty hodnotí známkou stupnice nejhůře 2. Hodiny byly (podle odpovědí) pro žáky přehlednější, úkoly byly důsledněji kontrolovány, prověřovaly probírané učivo. Podle slov vyučující je žáci vypracovávali sami doma a bez cizí pomoci.

Komunikace v angličtině byla běžnou součástí vyučování. Problémem, který se však nezřídka objevoval, byla rozdílná česká a anglická terminologie (požadována byla znalost obou). Ten jsme odstraňovali průběžně, spolu s odborníky (viz kap. 3.1). Zpočátku byla v hodinách matematiky v angličtině patrná nejistota, strach žáků, plynoucí z neznalosti terminologie (anglické a tím i české) a tím i z neznalosti matematiky. Nejistota se však v průběhu školního roku vytrácela zásluhou nového výukového prostředí, zavedením technologií a přístupu vyučujících (viz kap. 3.1).

V kategorii K3 Podpora žáka se průměrné hodnocení skupiny M liší o 0,44 bodu oproti skupině M/A. Z charakteristiky vyučující jsme očekávali dobré hodnocení této kategorie. Postoj žáků ve skupině M/A k otázkám K3 charakterizuje odpověd' skoro vždy $(2,08)$.

Změna výukových metod vedla k využití nových technologií, a tím i ke změně výukového prostředí. To pomohlo lepšímu pochopení pojmů, vysvětlení stejné věci několikrát s opakováním nebo parafrázováním, v připravených interaktivních testech docházelo ke kontrole porozumění s okamžitým vyhodnocením. Využitím nástrojů, které jsou součástí programů pro interaktivní tabule, byly pro žáky připraveny interaktivní testy, které žáci řešili s pomocí hlasovacího zařízení, výsledky byly po testu zveřejněny ve statistice řešení celé tř́ídy, včetně chybných, neúplných či nesprávných odpovědí. Proto také 
kategorie K4 - Spravedlivý prrístup byla hodnocena žáky M/A lépe, než ji hodnotili žáci $\mathrm{M}$. V hodinách matematiky skupina $\mathrm{M}$ interaktivní testy nepoužívala a hodnocení nebylo tak otevřené. Tuto skutečnost ovlivnil i fakt, že je velice obtížné stanovit dobrý způsob hodnocení ve výuce metodou CLIL. Proto je mu věnována značná pozornost. Otázky související s hodnocením jsou například širší škála průběžného hodnocení, validita, jazyk, typy otázek aj.

Z hodnocení kategorie K5 sledujeme pohled žáků směrem k využitelnosti matematiky $\mathrm{v}$ praxi, vytváření matematické gramotnosti, směřování k budoucí profesi. Opět žáci skupiny M/A hodnotí tuto kategorii lépe než žáci skupiny M, odchylka výsledků v této kategorii je 0,37.

Získaná data jsme dále testovali s cílem prokázat, zda jsou rozdíly v hodnocení žáků statisticky významné, či nikoliv. Data z šetření G jsme tentokrát považovali za normu, a porovnávali jsme pouze data, která jsme získali zadáním dotazníku skupinám $\mathrm{M}$ a M/A. Protože nelze předpokládat, že odpovědi na jednotlivé otázky mají normální rozdělení, byl pro testování hypotéz vybrán neparametrický Mann-Whitneyův test. Pro tyto účely byla nulová hypotéza formulována tak, že odpovědi žáků v obou skupinách M a M/A na otázky v jednotlivých kategoriích mají stejné rozdělení. Alternativní hypotéza byla formulována tak, že rozdělení není stejné. Testování hypotéz proběhlo pro každou ze sedmi kategorií odděleně, vždy na hladině významnosti $\alpha=5 \%$. Získané hodnoty jsou pro každou z kategorií K1 až K7 prezentovány $\mathrm{v}$ tabulce 2 (poslední sloupec). Jak je z uvedených hodnot $p$-value patrné, ve všech sedmi př́padech musíme zamítnout nulovou hypotézu ve prospěch hypotézy alternativní, tj. že ve všech sledovaných kategoriích je rozdělení odlišné. Střední hodnoty odpovědí jsou ve všech kategoriích skupiny M/A nižší (odpovídají lepšímu hodnocení). Můžeme proto oprávněně usuzovat, že je klima výuky matematiky skupinou M/A hodnoceno statisticky významně lépe, než je tomu u skupiny $\mathrm{M}$.

Příklady odpovědí na otázku „Jak hodnotíš výuku matematiky v angličtině?“, kterou jsme položili žákům v květnu 2011:

Ž1: „Je dobré, že si procvičím AJ. Baví mě pracovat s notebookem, učím se nová slovíčka a pracovat s interaktivní tabulí.“

Ž2: „Je to můj oblíbený předmět. Je tu zábava a není to jen nudné počítání. V angličtině je matika fakt dobrá. Baví mě to." 
Ž3: „Je to můj nejoblíbenější předmět. Je tu sranda a dobře se naučím angličtinu a matiku. Nejvíc mě baví rýsovat na notebooku."

Z uvedených výsledků dotazníkového šetření vyplývá, že v průběhu projektu došlo ke změně klimatu výuky matematiky. Změna souvisela s rozdílností výukových stylů v důsledku zavedení metody CLIL do výuky. Hodnocení skupiny $\mathrm{s}$ výukou matematiky v českém jazyce dosahovalo v dotazníku srovnatelných hodnot jako hodnocení skupiny respondentů dotazníkového šetření, sledujícího klima př́rodovědných předmětů (Grecmanová, 2008), v hodinách s výukou v anglickém jazyce se hodnocení klimatu výuky zlepšilo. Fraser a Tobin (1991) konstatují, že klima třídy ovlivňuje chování studentů, úroveň znalostí, studijní výsledky, motivace, postoje $\mathrm{k}$ vyučované oblasti a vzdělání jako celku. Výsledky hodnocení jednotlivých kategorií dotazníku ukazují zlepšení uvedených postojů. Dále při výuce matematiky v angličtině probíhala výuka průřezových témat, jako je multikulturní výchova a výchova v evropských a globálních souvislostech vzhledem k vyučovanému jazyku. Žáci uváděli, že skoro vždy vidí souvislost matematiky se životem kolem sebe. Dreesmann (1982) uvádí, že klima výuky matematiky a angličtiny je rozdílné. V našem šetření klima výuky matematiky a angličtiny žáci nevnímali jako oddělené a rozdílné situace, ale došlo ke spojení vnímání obou v jediném celku.

\section{Diskuze a závěr}

Klima výuky se tvoří především na základě interakce učitel - žák, je proto determinováno osobností učitele, žáka a vyučovacím předmětem. $\mathrm{V}$ tomto př́spěvku jsme se zabývali otázkou, zda při výuce matematiky metodou CLIL dojde ke změně klimatu. Vycházeli jsme především z výsledkủ šetření klimatu výuky př́rodovědných předmětů Grecmanové (2008, s. 127).

Popsali jsme související proměnné v souvislosti s posouzením klimatu výuky. $\mathrm{Z}$ našich dosavadních zkušeností z práce na projektu a z rozhovorů $\mathrm{s}$ respondenty plyne, že se změnil přístup vyučujících $\mathrm{k}$ výuce. Hledají nové, aktivizující metody, pracují s novým prostředím, s novými technologiemi, a to je dobrý prostředek proti rutině. Dále jsme při analýze výsledkủ výuky matematiky sledovali závislost výsledku na vnímání dobrého př́stupu učitele. Žáci, které výuka baví a kteří se v hodinách nenudí, dosahují lepších výsledků. To se odrazilo i v jejich hodnocení zkoumaných kategorií v dotazníku. Problémem v úspěšné implementaci výuky metodou CLIL na základních a středních školách je však nedostatek kvalifikovaných učitelů pro tento 
druh výuky a obava učitelů, zda takovou výuku zvládnou. Je to způsobeno jak neznalostí cizího jazyka, tak i obavami, zda takovou výuku dokáží připravit a uskutečnit. Naše studie také ukazuje, že při výuce matematiky metodou CLIL (oproti běžným hodinám matematiky) nemusí chybět individuální přístup k žákům, komunikace a tlak na žáky směrem k výkonu nemusí mít negativní účinky na jejich pocity, kterými hodnotí klima výuky. Jednu zajímavost uvádí učitelka, jejíž klima výuky jsme měřili: „... žáci, kteří dosud byli v matematice neaktivní, začali matematiku vidět z jiného úhlu pohledu, jako by se vzbudila jejich vnitřní motivace“.

Také Novotná a Hofmannová (2000, s. 228) uvádí, že s metodou CLIL ve vyučování matematice úzce souvisí aktivní zapojení žáků do učebního procesu, využití široké škály nonverbálních prostředků komunikace a různých forem reprezentace (vizualizace, modelování, využití schematických a symbolických zápisů, grafických organizátorů apod.), zajímavý, praktický a poutavý výběr učiva, volba odpovídajících organizačních forem výuky aj. Významným přínosem používání metody CLIL je skutečnost, že žákům rozšiŕí prŕležitosti přijímat a zároveň i prakticky používat cizí jazyk. Neučí se cizí jazyk bez zjevného spojení s vlastní budoucností, mohou ho tedy ihned používat. Zkušenosti ukazují, že žáci pracují v cizím jazyce usilovněji a snaží se porozumět novým pojmům. $V$ neposlední řadě tímto způsobem roste žákům postupně sebevědomí při používání cizího jazyka, protože si $\mathrm{v}$ reálných situacích během vyučovací hodiny procvičují komunikaci a porozumění. Ještě uved'me, že metodu CLIL je možné úspěšně začlenit jako výukovou metodu do vyučování matematiky na škole v dané časové dotaci určené pro tento předmět (Šulista, 2010).

Cílem výzkumu bylo popsat změnu klimatu výuky matematiky v souvislosti se zavedením metody CLIL. Dospěli jsme k závěru, že klima výuky matematiky $\mathrm{v}$ angličtině je rozdílné oproti klimatu výuky matematiky $\mathrm{v}$ češtině. Klima výuky matematiky $\mathrm{v}$ angličtině žáci vnímají více pozitivně. Nepotvrdily se prvotní obavy vyučujících (na začátku projektu), že metoda CLIL vyvolá u žáků, kteří matematiku nemají rádi, ještě větší obavy, strach a nechut' k práci a to se negativně projeví na vnímání klimatu výuky. Otázkou je, zda zavedením metody CLIL do výuky matematiky nedošlo ke zhoršení znalostí žáků z matematiky, zda se změnil jejich vztah k matematice. To je předmětem souvisejících výzkumů a testování. 
Na závěr je třeba zdůraznit, že není cílem této studie výsledky zobecnit, jde o omezený vzorek. Zůstávají nezodpovězeny otázky týkající se podstaty klimatu jako dynamického sociálního jevu. Otázkou také je, zda a za jakých podmínek je uvedený projekt přenositelný na jakoukoli základní školu. Studie vychází z dat sebraných na jedné škole, celkem od 180 žáků. S rozšířením vzorku žáků bychom museli vzít v potaz charakteristiky osobností participujících učitelů, úrovně žáků, školy apod. Bylo by ku prospěchu takového šetření pořídit řízené rozhovory se žáky a učiteli a dát výzkumu rozměr z obou perspektiv, jak žáka, tak učitele. Přesto však je projekt, jehož dílčí výsledky předkládáme, jedinečný, nebot' není jiná škola v České republice, která by začlenila metodu CLIL do vyučování ve všech třídách a v tak dlouhém období. Ve většině obdobných projektů se jedná o jednu až dvě třídy v jedné škole.

\section{Literatura}

Allen, D., \& Fraser, J. (2007). Parent and student perceptions of classroom learning environment and its association with student outcomes. Learning Environment Research, 10(1), 67-82.

Allodi, M. W. (2007). Assessing the quality of learning environments in Swedish schools: Development and analysis of a theory-based instrument. Learning Environments Research, 10(3), 157-175.

Davies, S. (2003). Content based instruction in EFL contexts. The Internet TESL Journal, 9(2), 24-28.

Dreesmann, H. (1982). Unterrichtsklima. Weinheim: Beltz Verlag.

Fraser, B. J. (1986). Classroom environment. London: Croom Helm.

Fraser, B. J., \& Tobin, K. (1991). Combining qualitative methods in classroom environment research. In B. J. Fraser \& H. J. Walberg (Eds.), Educational environment: Evaluation, antecedents and consequences (s 271-292). Oxford: Pergamon Press.

Grecmanová, H. (2008). Klima školy. Olomouc: Hanex.

Koncepce matematické gramotnosti ve výzkumu PISA 2003 (2004). Praha: Ústav pro informace ve vzdělávání.

Lambert, N. M., \& McCombs, B. L. (Eds.). (1998). How students learn: Reforming schools through learner centered education. Washington, DC: American Psychological Association.

Lambert R., Abbott-Shim, M., \& McCarty, F. (2002). The relationship between classroom quality and ratings of the social functioning of head start children. Early Child Development and Care, 172(3), 231-245.

Lange, G. (Ed). (2002). TIE-CLIL Professional development course. Milan: M.I.U.R.

Lave, J. (1988). Cognition in practice. Cambridge: Cambridge University Press.

Lewis, G. E. (1977). Bilingual in education-cross-national research. International Journal of the Sociology of Language, 1977(14), 26-52.

Mareš, J. (2000). Sociální klima školy. Pedagogická revue, 52(3), 241-254.

Marsh, D. (2000). Using languages to learn and learning to use languages. University of Jyväskylä: UniCOM. 
Novotná, J., \& Hofmannová, M. (2000). CLIL and mathematics education. In A. Rogerson (Ed), Proceedings of the international conference Mathematics for living (pp. 226-230). Amman: The Mathematics Education into the 21st Century Project.

Oxford, R. (2001). Integrated skills in the ESL/EFL classroom. ESL Magazine, 4(1), 18-20.

Rutter, M. (2000). School effects on pupil progress: Research findings and policy implications. In P. K. Smith \& A. D. Pellegrini (Eds.), Psychology of education: Major Themes (2-42). London: Falmer Press.

Salomon, G. (1992). New challenges for educational research: Studying the individual within learning environments. Scandinavian Journal of Educational Research, 36(3), 167-183.

Schwartz, S. H. (1992). Universals in the content and structure of values: Theoretical advances and empirical tests in 20 countries. In M. P. Zanna (Ed.), Advances in experimental psychology (1-65). London: Academic Press.

Snow, M. A., Met, M., \& Genesee, F. (1989). A conceptual framework for the integration of language and content in second/foreign language instruction. Tesol Quarterly, 23(2), 201-217.

Stigler, J. W., \& Hiebert, J. (1999). The teaching gap. New York: Free Press.

Swain, M., \& Lapkin, S. (1982). Evaluating bilingual education: A canadian case study. Clevedon: Multilingual Matters.

Šulista, M. (2010). Analysis of the initial implementation ofCLIL in mathematics lessons (Disertační práce). Praha: Pedagogická fakulta Univerzity Karlovy v Praze.

The PISA 2003 assessment framework - mathematics, reading, science and problem solving knowledge and skills (2003). Paris: OECD.

\title{
Autorka
}

RNDr. Helena Binterová, Ph.D., Jihočeská univerzita, Pedagogická fakulta, Katedra matematiky, Jeronýmova 10, 37115 České Budějovice, e-mail: hbinter@pf.jcu.cz

\section{Climate of mathematics through English instruction (CLIL method)}

\begin{abstract}
The paper presents a case study focusing on the climate of the teaching of mathematics in a concrete school. The quantitative characteristics of the climate are based on questionnaires and interviews. The study presents research results conducted in connection with implementation of the teaching of mathematics in a foreign language. After analyzing interviews with teachers and pupils together with the analysis of the questionnaires, the paper describes changes of the climate of the mathematics teaching in a different language than the mother tongue from the teachers' as well as the pupils' point of view. At the same time, the paper identifies possible causes of the changes and describes in detail teaching methods and characteristics of the teaching and learning environment.
\end{abstract}

Keywords: educational climate, CLIL method, learning environment 